\title{
Populasi Elaeidobius kamerunicus Faust (Coleoptera: Curculionidae) pada beberapa umur tanaman kelapa sawit
}

\author{
Population site of Elaeidobius kamerunicus Faust (Coleoptera: \\ Curculionidae) on different age of oil palm plantation
}

\author{
Bambang Tri Rahardjo ${ }^{{ }^{*}}$, Akhmad Rizali ${ }^{1}$, Ika Putri Utami ${ }^{1}$, Sri Karindah ${ }^{1}$, \\ Retno Dyah Puspitarini ${ }^{1}$, Bandung Sahari ${ }^{2}$ \\ 'Jurusan Hama dan Penyakit Tumbuhan, Fakultas Pertanian, Universitas Brawijaya \\ Jalan Veteran, Malang 65145 \\ ${ }^{2} \mathrm{PT}$. Astra Agro Lestari \\ Jalan Puloayang Raya Blok OR-1, Kawasan Industri Pulogadung, Jakarta 13930
}

(diterima Februari 2018, disetujui Maret 2018)

\begin{abstract}
ABSTRAK
Kumbang Elaeidobius kamerunicus Faust merupakan serangga polinator kelapa sawit yang hidup pada bunga jantan dan mengunjungi bunga betina untuk melakukan penyerbukan karena ketertarikan terhadap senyawa volatil yang dikeluarkan. Kuantitas fruit set kelapa sawit yang dihasilkan berhubungan dengan populasi $E$. kamerunicus pada suatu lahan. Penelitian ini bertujuan untuk mempelajari pengaruh umur tanaman kelapa sawit terhadap populasi kumbang E. kamerunicus. Penelitian dilakukan di perkebunan kelapa sawit yang terletak di Pangkalan Lada, Kotawaringin Barat, Kalimantan Tengah. Metode penelitian yang digunakan adalah berupa penghitungan populasi E. kamerunicus pada bunga jantan dan pemasangan sticky trap pada bunga betina. Plot pengamatan berukuran $7000 \mathrm{~m}^{2}(100$ pohon) dengan variasi umur tanaman kelapa sawit, yaitu 6,10 , dan 16 tahun. Setiap plot dihitung jumlah bunga jantan dan betina yang mekar dan ditentukan beberapa bunga untuk pengukuran populasi $E$. kamerunicus yang dilakukan setiap bulan selama tiga bulan pengamatan. Hasil penelitian menunjukkan bahwa umur tanaman kelapa sawit berpengaruh terhadap populasi E. kamerunicus pada bunga jantan tapi tidak pada bunga betina. Semakin tua umur kelapa sawit, populasi E. kamerunicus pada bunga jantan semakin meningkat. Rasio jenis kelamin E. kamerunicus yang ditemukan pada bunga jantan dan betina kelapa sawit cenderung bias betina. Berdasarkan perbandingan populasi E. kamerunicus pada bunga jantan dan betina pada setiap plot diperoleh bahwa nilai kunjungan E. kamerunicus paling tinggi ditemukan pada umur kelapa sawit muda. Sebagai kesimpulan, pertambahan umur kelapa sawit mempengaruhi peningkatan populasi $E$. kamerunicus pada bunga jantan tapi persentase kunjungan ke bunga betina menjadi semakin menurun.
\end{abstract}

Kata kunci: Elaeidobius kamerunicus, kelapa sawit, penyerbuk, umur tanaman

\begin{abstract}
Elaeidobius kamerunicus Faust is an oil palm pollinator insect that lives on the male inflorescence and visits female inflorescence to pollinate due to attracted by its volatile compound. The number of fruit sets of oil palm relates to the population of E. kamerunicus on a plantation. The objective of this study was to investigate the effect of age of oil palm on the population of E. kamerunicus. Field research was conducted in oil palm plantations that located in Pangkalan Lada, Kotawaringin Barat District, in Central Kalimantan. The research method was by measurement of E. camerunicus population on male

\footnotetext{
*Penulis korespondensi: Bambang Tri Rahardjo. Jurusan Hama dan Penyakit Tumbuhan, Fakultas Pertanian, Universitas Brawijaya
}

Jalan Veteran, Malang 65145. Tel: 0341-575843, Faks: 0341-579237, Email: bambang_bejos@yahoo.com
\end{abstract}


inflorescences and set up the sticky trap on female inflorescences. Plot with size $7000 \mathrm{~m}^{2}$ (100 trees) was selected on several ages of oil palm i.e. 6, 10 and 16 years. Each plot, the number of male and female inflorescences was counted and some inflorescences were chosen for measurement of $E$. camerunicus population that was conducted monthly for three months of observation. The results showed that the age of the oil palm affected the population of E. kamerunicus in male inflorescences but not in female inflorescences. The older age of oil palm, the population of E. kamerunicus in male flowers was increasing. The sex ratio of E. kamerunicus found in male and female inflorescences of oil palms tend to female bias. Based on the comparison of E. kamerunicus population between male and female inflorescences on each plot, it was found that visitation value of E. kamerunicus was highest in the young oil palm. In conclusion, increasing age of oil palm trees affected on increasing of E. kamerunicus population in male inflorescences, but visitation value on female inflorescences prone to decline.

Key words: Elaeidobius kamerunicus, oil palm, pollinator, plant age

\section{PENDAHULUAN}

Kelapa sawit Elaeis guineensis Jacq. (Arecaceae) merupakan jenis tanaman yang sifat bunganya berumah satu (monocius), yaitu bunga jantan dan betina terdapat pada satu pohon. Waktu mekar bunga jantan kelapa sawit berlangsung selama 4-5 hari, sedangkan bunga betina berlangsung selama 36-48 jam (Sunarko 2007). Pada satu pohon kelapa sawit jarang ditemukan bunga jantan dan bunga betina mekar pada waktu yang bersamaan (Rahmadani \& Achmad 2015). Perbedaan kematangan bunga jantan dan bunga betina tersebut menyebabkan penyerbukan bunga kelapa sawit berlangsung secara silang (Situmeang et al. 2017). Proses penyerbukan pada bunga kelapa sawit memerlukan agens penyerbuk sebagai pembawa serbuk sari dari bunga jantan ke bunga betina yang sedang mekar dari pohon yang lain (Simatupang 2014).

Elaeidobius kamerunicus Faust merupakan serangga polinator yang paling efisien dan mudah beradaptasi pada bunga jantan kelapa sawit (Balit Palma 2015). E. kamerunicus mendapatkan sumber makan dan berkembang biak pada bunga jantan kelapa sawit (Prasetyo \& Susanto 2012). E. kamerunicus mengunjungi bunga betina mekar karena adanya aroma senyawa kimia p-metosialilbenzena (estrgole) (Agus et al. 2007). Sejak adanya introduksi E. kamerunicus sebagai serangga penyerbuk kelapa sawit di Indonesia, secara umum terjadi peningkatan berat tandan dan fruit set kelapa sawit (Tandon et al. 2001; Lubis et al. 2017). Fruit set yang baik pada kelapa sawit nilainya di atas $75 \%$ yang dapat dicapai dengan kehadiran minimal sekitar 20.000 individu $E$. kamerunicus per hektar (Balit Palma 2015).

32
Upaya untuk meningkatkan hasil fruit set kelapa sawit dapat dilakukan dengan mengoptimalkan populasi E. kamerunicus sehingga tidak kurang dari jumlah minimal yang harus tersedia di lapangan (Kahono et al. 2012). Selain itu, tingkat keberhasilan penyerbukan oleh E. kamerunicus pada bunga betina memerlukan perhatian yang cermat dan perlu untuk mengetahui persentase populasi E. kamerunicus yang mengunjungi bunga betina kelapa sawit. Populasi E. kamerunicus juga dipengaruhi oleh umur tanaman kelapa sawit (Tandon et al. 2001). Informasi terkait populasi E. kamerunicus pada bunga jantan dan populasi E. kamerunicus yang mengunjungi bunga betina pada berbagai umur tanaman kelapa sawit belum banyak dilaporkan. Penelitian sebelumnya lebih banyak difokuskan pada umur kelapa sawit tertentu (Wibowo 2010; Harumi 2011). Penelitian ini bertujuan untuk (i) mempelajari populasi E. kamerunicus pada bunga jantan dan betina pada berbagai umur tanaman kelapa sawit dan (ii) mengkaji hubungan umur tanaman dengan banyaknya kunjungan $E$. kamerunicus pada bunga betina kelapa sawit.

\section{BAHAN DAN METODE}

\section{Lokasi penelitian dan penentuan plot penga- matan}

Penelitian dilaksanakan di perkebunan kelapa sawit milik PT. Astra Agro Lestari pada kawasan Agro Menara Rahmat yang terletak di Desa Pandu Senjaya, Kecamatan Pangkalan Lada, Kabupaten Kotawaringin Barat, Kalimantan Tengah. Plot pengamatan adalah lahan kelapa sawit dengan umur yang berbeda, yaitu 6, 10, dan 16 tahun. 
Sebagai ulangan, pada setiap umur tanaman sawit ditentukan tiga lokasi pengamatan yang berbeda (Gambar 1).

Di setiap lokasi, plot pengamatan berukuran sekitar $7000 \mathrm{~m}^{2}$ atau terdiri atas 100 pohon kelapa sawit. Setiap bulan, yaitu mulai bulan Maret hingga Mei 2016 dilakukan penghitungan jumlah bunga jantan dan bunga betina mekar yang terdapat di dalam plot tersebut. Beberapa bunga jantan dan betina dipilih sebagai unit contoh untuk pengamatan populasi E. kamerunicus.

\section{Penghitungan populasi E. kamerunicus pada bunga jantan}

Bunga jantan mekar disungkup menggunakan pollination bag dan dilakukan pemotongan tandan bunga jantan. Setelah itu, dilakukan penyemprotan insektisida berbahan aktif d-aletrin pada tandan bunga jantan yang terdapat dalam pollination bag. Pemisahan E. kamerunicus dari tandan bunga jantan dan penghitungan populasi E. kamerunicus jantan dan betina dilakukan di laboratorium. Penghitungan populasi di lakukan secara manual menggunakan hand counter.

\section{Penghitungan populasi $E$. kamerunicus pada bunga betina}

Pengamatan populasi E. kamerunicus pada bunga betina dilakukan dengan cara memasang perangkap. Perangkap yang di gunakan berupa plastik mika berukuran $10 \mathrm{~cm}$ x $15 \mathrm{~cm}$ yang telah diberi lem perekat. Perangkap di pasang menutupi keseluruhan permukaan bunga betina reseptif dan pada masing-masing bunga betina dipasang 4 buah perangkap. E. kamerunicus yang terdapat pada perangkap kemudian dikoleksi dan dilakukan penghitungan populasinya.

\section{Identifikasi $E$. kamerunicus dan pembedaan serangga jantan dan betina}

Untuk melakukan identifikasi dan membedakan E. kamerunicus jantan dan betina digunakan kunci identifikasi yang tersedia (Walker 2011). Panjang tubuh E. kamerunicus jantan adalah 3$4 \mathrm{~mm}$, sedangkan panjang tubuh betina lebih kecil, yaitu 2-3 mm. Kumbang jantan memiliki tonjolan pada pangkal elitra, sedangkan kumbang betina tidak memiliki tonjolan. Pada bagian abdomen jantan terdapat rambut-rambut halus yang lebih banyak daripada kumbang betina yang hanya memiliki sedikit rambut-rambut halus. Moncong kumbang jantan lebih pendek daripada kumbang betina.

\section{Analisis data}

Data jumlah bunga kelapa sawit jantan dan betina yang diamati berbeda untuk setiap plot dan waktu pengamatan sehingga untuk membandingkan

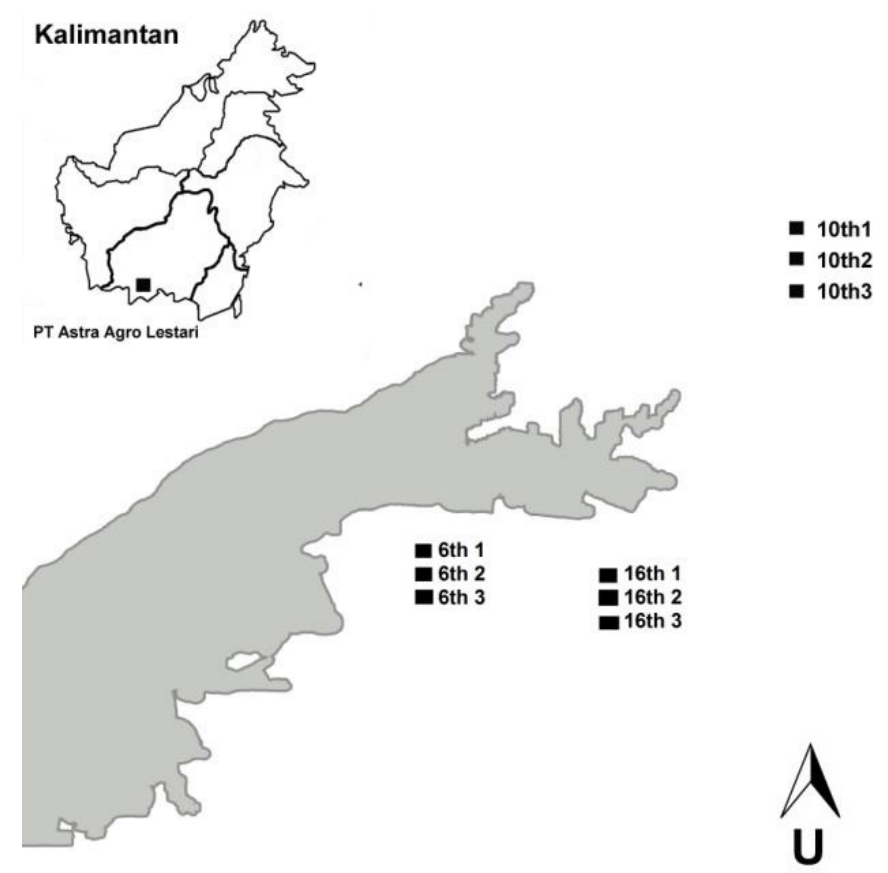

Gambar 1. Lokasi plot pengamatan pada berbagai umur tanaman (kotak hitam) yang terletak berdekatan dengan habitat alami (warna abu-abu). 
populasi E. kamerunicus pada bunga jantan dan bunga betina pada umur tanaman kelapa sawit berbeda, digunakan data rata-rata per bunga (atau per pohon) untuk setiap plot. Perbedaan populasi E. kamerunicus dianalisis dengan menggunakan analisis ragam (ANOVA) faktorial dengan mempertimbangkan umur tanaman sawit dan waktu pengamatan yang berbeda. Analisis korelasi juga digunakan untuk melihat hubungan populasi $E$. kamerunicus yang mengunjungi bunga jantan dan bunga betina pada berbagai umur tanaman kelapa sawit. Untuk menentukan nilai kunjungan $E$. kamerunicus pada bunga betina, digunakan asumsi bahwa populasi E. kamerunicus pada bunga betina berasal bunga jantan dari plot yang sama. Nilai kunjungan dihitung berdasarkan total populasi $E$. kamerunicus yang ditemukan pada bunga betina dibandingkan dengan total populasi pada bunga jantan kelapa sawit dikali 100\%.

\section{HASIL}

Populasi E. kamerunicus pada umur tanaman kelapa sawit yang berbeda

Populasi E. kamerunicus pada bunga jantan. Jumlah bunga jantan yang ditemukan per plot berkisar 6-7 bunga dengan populasi E. kamerunicus berkisar 5.137-14.121 individu per bunga (Tabel 1). Umur tanaman berpengaruh terhadap populasi E. kamerunicus pada bunga jantan kelapa sawit $\left(\mathrm{F}_{2,22}=11,130 ; \mathrm{P}=0,0005\right)(\mathrm{Gambar} 2 \mathrm{~A})$. Populasi E. kamerunicus tertinggi ditemukan pada kelapa sawit umur 16 tahun (14.121 individu/bunga atau 139.827 individu/ha), sedangkan populasi terendah pada kelapa sawit umur 6 tahun (5.137 individu/bunga atau 53.119 individu/ha). Populasi E. kamerunicus yang terdapat pada tandan bunga jantan tidak menunjukkan perbedaan antar waktu pengamatan berbeda pada umur tanaman yang sama $\left(F_{2,22}=0,940 ; P=0,406\right)($ Gambar 3A).

Hasil analisis korelasi menunjukkan bahwa terdapat hubungan antara jumlah spikelet per tandan bunga jantan dan umur tanaman kelapa sawit. Semakin tua umur tanaman kelapa sawit, jumlah spikelet yang terdapat pada bunga jantan cenderung semakin banyak $(\mathrm{r}=0,959 ; \mathrm{P}<0,0001)$. Selain itu, populasi E. kamerunicus pada bunga jantan juga berkorelasi dengan jumlah spikelet, yaitu semakin banyak jumlah spikelet maka populasi E. kamerunicus juga menjadi semakin tinggi $(\mathrm{r}=0,758 ; \mathrm{P}<0,0001)$.

Populasi E. kamerunicus pada bunga betina. Jumlah bunga betina yang ditemukan per plot berkisar 2-4 bunga dengan populasi E. kamerunicus berkisar 1.096-2.224 individu per bunga (Tabel 1). Umur tanaman tidak berpengaruh terhadap populasi E. kamerunicus yang mengunjungi bunga betina kelapa sawit $\left(\mathrm{F}_{2,22}=2,717 ; \mathrm{P}=0,088\right)$ (Gambar 2B). Untuk umur tanaman yang sama, populasi E. kamerunicus yang mengunjungi bunga betina tidak menunjukkan perbedaan antar waktu pengamatan berbeda $\left(\mathrm{F}_{2,22}=1,102 ; \mathrm{P}=0,349\right)$ (Gambar 3B).

Tabel 1. Jumlah bunga jantan dan betina kelapa sawit (per plot dan estimasi per ha dalam rerata \pm SB) dan populasi Elaeidobius kamerunicus yang ditemukan (per bunga dan estimasi per ha dalam rerata \pm SB) pada umur tanaman kelapa sawit berbeda

\begin{tabular}{lccc}
\hline \multirow{2}{*}{ Variabel } & \multicolumn{3}{c}{ Umur tanaman (tahun) } \\
\cline { 2 - 4 } & 6 & 10 & 16 \\
\hline Jumlah bunga & & & $6,9 \pm 1,2$ \\
Bunga jantan per plot & $7,1 \pm 1,5$ & $6,1 \pm 1,1$ & $9,8 \pm 1,7$ \\
per ha & $10,2 \pm 2,1$ & $8,7 \pm 1,5$ & $2,1 \pm 0,3$ \\
Bunga betina per plot & $4,1 \pm 0,9$ & $3,8 \pm 0,7$ & $3,0 \pm 0,5$ \\
per ha & $5,9 \pm 1,3$ & $5,4 \pm 1,0$ & \\
Populasi E. kamerunicus & & & $14.121 \pm 5.365$ \\
Bunga jantan per bunga & & & \\
per ha & $5.137 \pm 2.283$ & $8.174 \pm 4.051$ & $2.224 \pm 1.535$ \\
Bunga betina per bunga & $53.119 \pm 28.516$ & $70.770 \pm 37.719$ & $6.737 \pm 4.583$ \\
per ha & $1.391 \pm 802$ & $1.096 \pm 657$ &
\end{tabular}



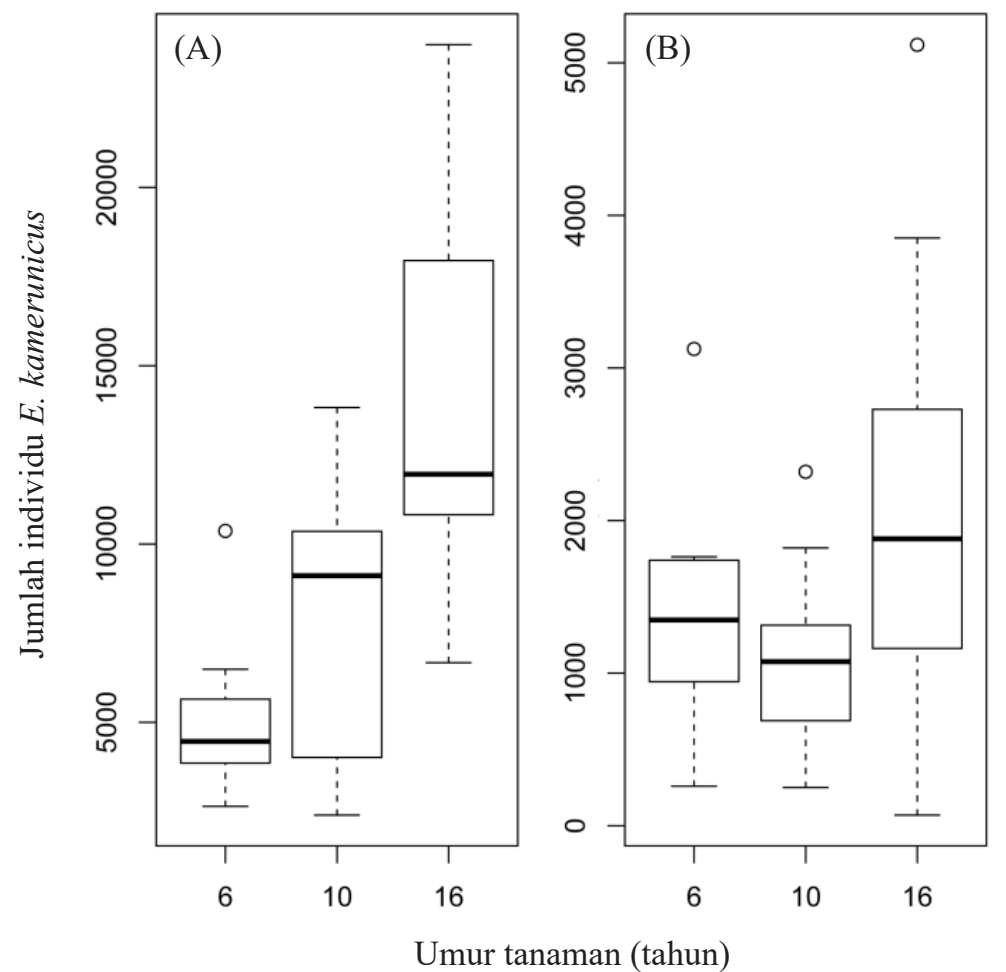

Gambar 2. Populasi Elaeidobius kamerunicus (rata-rata per bunga) pada A: bunga jantan $\left(\mathrm{F}_{2,22}=11,130\right.$, $\mathrm{P}=0,0005)$; dan $\mathrm{B}$ : bunga betina $\left(\mathrm{F}_{2,22}=2,717, \mathrm{P}=0,088\right)$ kelapa sawit dengan umur tanaman berbeda.
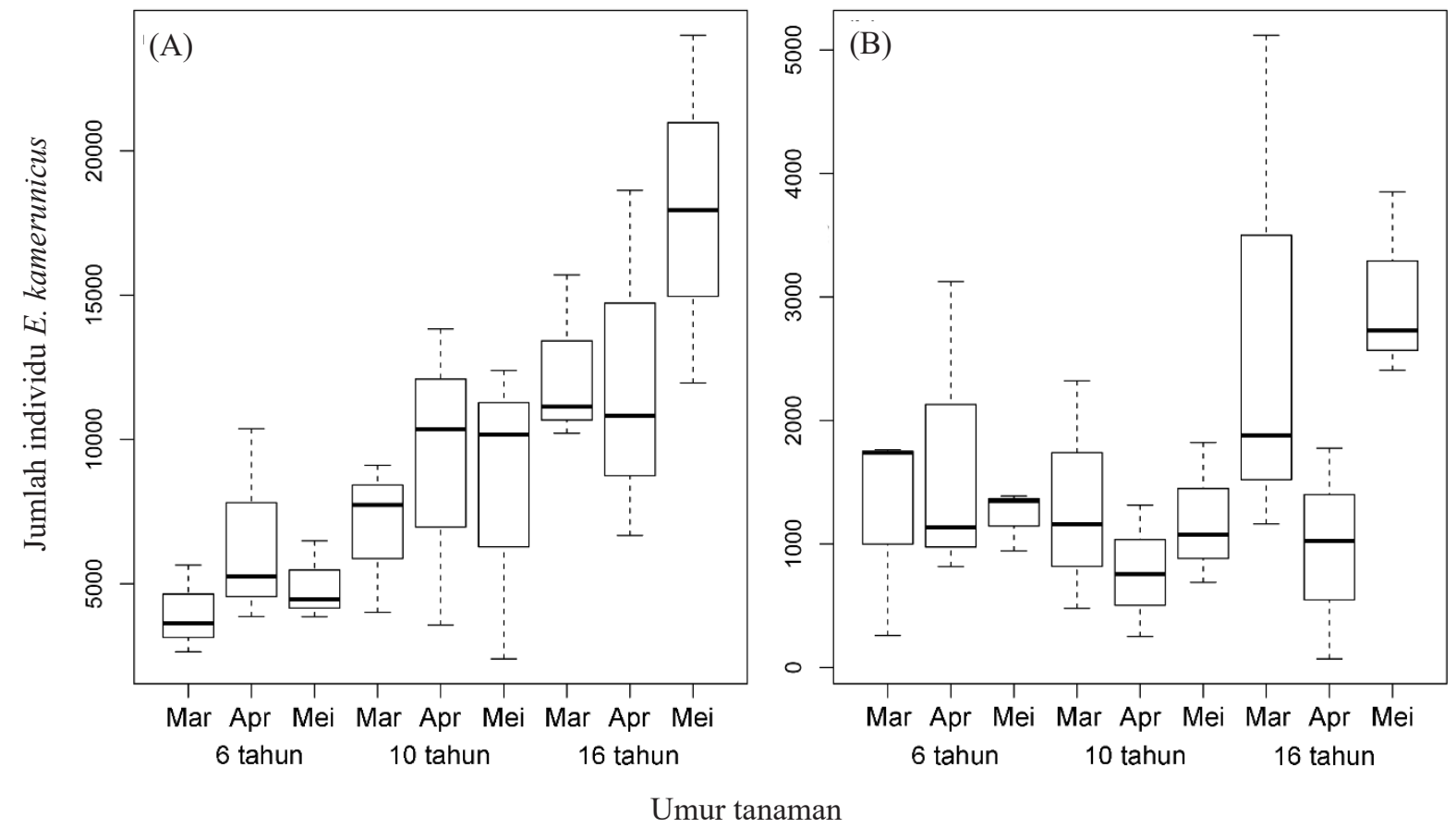

Gambar 3. Populasi Elaeidobius kamerunicus pada A: bunga jantan; dan B: bunga betina kelapa sawit pada waktu pengamatan berbeda. Tidak terdapat perbedaan populasi antar waktu pengamatan pada umur tanaman yang sama baik pada bunga jantan maupun bunga betina $(\mathrm{P}>0,05)$. 
Populasi E. kamerunicus jantan dan betina pada tanaman kelapa sawit dengan umur berbeda

Populasi $E$. kamerunicus jantan dan betina pada bunga jantan kelapa sawit. Populasi $E$. kamerunicus jantan dan betina pada bunga jantan ditemukan tertinggi pada kelapa sawit umur 16 tahun, sedangkan populasi terendah, yaitu pada kelapa sawit umur 6 tahun (Tabel 2, Gambar 4AB). Semakin tua umur tanaman kelapa sawit maka populasi E. kamerunicus jantan $\left(\mathrm{F}_{2,22}=9,761 ; \mathrm{P}\right.$ $=0,0009)$ dan betina $\left(\mathrm{F}_{2,22}=11,110 ; \mathrm{P}=0,0005\right)$ yang terdapat pada bunga jantan kelapa sawit semakin tinggi. Waktu pengamatan berbeda tidak mempengaruhi perbedaan populasi $E$. kamerunicus jantan $\left(\mathrm{F}_{2,22}=0,640 ; \mathrm{P}=0,536\right)$ dan betina $\left(\mathrm{F}_{2,22}=\right.$ $1,070 ; \mathrm{P}=0,360)$ pada bunga bunga jantan. Selain itu, hasil pengukuran nisbah kelamin kumbang $E$. kamerunicus pada bunga jantan dengan berbagai umur kelapa sawit menunjukkan lebih bias betina, yaitu rasio jantan : betina antara $1: 2,1$ hingga 1 : 2,9 (Tabel 2).

Populasi $E$. kamerunicus jantan dan betina pada bunga betina kelapa sawit. Umur tanaman tidak mempengaruhi populasi E. kamerunicus jantan $\left(\mathrm{F}_{2,22}=2,811 ; \mathrm{P}=0,082\right)$ dan betina $\left(\mathrm{F}_{2,22}=\right.$ $2,656 ; \mathrm{P}=0,093)$ yang mengunjungi bunga betina kelapa sawit (Tabel 2, Gambar 4C-D). Waktu pengamatan juga tidak mempengaruhi populasi $E$. kamerunicus jantan $\left(\mathrm{F}_{2,22}=1,128 ; \mathrm{P}=0,342\right)$ dan betina $\left(\mathrm{F}_{2,22}=1,084 ; \mathrm{P}=0,356\right)$ yang mengunjungi bunga betina. Hasil pengukuran nisbah kelamin E. kamerunicus yang mengunjungi bunga betina lebih banyak betina daripada jantannya, yaitu dengan rasio jantan : betina antara $1: 2,0$ hingga $1: 2,3$ (Tabel 2).

\section{Hubungan populasi E. kamerunicus pada bunga jantan dengan bunga betina kelapa sawit}

Di dalam penelitian ini, populasi $E$. kamerunicus yang mengunjungi tandan bunga betina mekar diasumsikan merupakan populasi $E$. kamerunicus yang berasal dari tandan bunga jantan dalam satu plot yang sama. Berdasarkan nilai persentase kunjungan, populasi E. kamerunicus pada bunga jantan yang mengunjungi bunga betina menunjukkan perbedaan pada umur tanaman berbeda $\left(\mathrm{F}_{2,22}=9,333 ; \mathrm{P}=0,001\right)$. Tanaman berumur 6 tahun lebih memiliki rerata nilai kunjungan lebih tinggi (16,9\%) dibandingkan dengan tanaman berumur 16 tahun (4,9\%) (Tabel 2). Hasil uji korelasi menunjukkan bahwa umur tanaman memiliki hubungan dengan populasi $E$. kamerunicus pada bunga jantan yang mengunjungi bunga betina. Semakin tua umur tanaman maka nilai kunjungan $E$. kamerunicus menjadi semakin rendah $(r=-0,586 ; P=0,001)$ (Tabel 2). Selain itu, peningkatan umur tanaman kelapa sawit

Tabel 2. Populasi dan rasio Elaeidobius kamerunicus jantan dan betina pada bunga jantan dan bunga betina kelapa sawit per plot dengan umur tanaman serta waktu pengamatan berbeda

\begin{tabular}{|c|c|c|c|c|c|c|c|c|c|c|}
\hline \multirow{2}{*}{$\begin{array}{l}\text { Umur } \\
\text { (tahun) }\end{array}$} & \multirow{2}{*}{ Pengamatan } & \multicolumn{4}{|c|}{ E. kamerunicus pada bunga jantan } & \multicolumn{4}{|c|}{ E. kamerunicus pada bunga betina } & \multirow{2}{*}{$\begin{array}{c}\text { Kunjungan } \\
(\%)^{*)}\end{array}$} \\
\hline & & Jantan & Betina & Rasio & Total & Jantan & Betina & Rasio & Total & \\
\hline \multirow[t]{4}{*}{6} & Maret & 7.539 & 16.331 & $1: 2,2$ & 23.870 & 2.034 & 4.236 & $1: 2,1$ & 6.270 & 26,3 \\
\hline & April & 14.749 & 37.216 & $1: 2,5$ & 51.965 & 1.899 & 4.307 & $1: 2,3$ & 6.206 & 11,9 \\
\hline & Mei & 11.537 & 24.669 & $1: 2,1$ & 36.205 & 1.371 & 3.127 & $1: 2,3$ & 4.498 & 12,4 \\
\hline & Rerata & 11.275 & 26.072 & $1: 2,3$ & 37.346 & 1.768 & 3.890 & $1: 2,2$ & 5.658 & 16,9 \\
\hline \multirow[t]{4}{*}{10} & Maret & 9.559 & 27.530 & $1: 2,9$ & 37.089 & 1.616 & 3.662 & $1: 2,3$ & 5.279 & 14,2 \\
\hline & April & 15.107 & 37.317 & $1: 2,5$ & 52.424 & 1.030 & 2.066 & $1: 2,0$ & 3.096 & 5,9 \\
\hline & Mei & 16.539 & 44.455 & $1: 2,7$ & 60.994 & 1.239 & 2.745 & $1: 2,2$ & 3.985 & 6,5 \\
\hline & Rerata & 13.735 & 36.434 & $1: 2,7$ & 50.169 & 1.295 & 2.824 & $1: 2,2$ & 4.120 & 8,9 \\
\hline \multirow[t]{4}{*}{16} & Maret & 25.382 & 52.830 & $1: 2,1$ & 78.212 & 1.651 & 3.789 & $1: 2,3$ & 5.441 & 7,0 \\
\hline & April & 23.139 & 65.172 & $1: 2,8$ & 88.311 & 598 & 1.314 & $1: 2,2$ & 1.912 & 2,2 \\
\hline & Mei & 36.577 & 89.213 & $1: 2,4$ & 125.791 & 2.210 & 4.780 & $1: 2,2$ & 6.991 & 5,6 \\
\hline & Rerata & 28.366 & 69.072 & $1: 2,4$ & 97.438 & 1.487 & 3.294 & $1: 2,2$ & 4.781 & 4,9 \\
\hline
\end{tabular}

*Kunjungan dihitung berdasarkan total populasi E. kamerunicus yang ditemukan pada bunga betina dibandingkan dengan total populasi pada bunga jantan kelapa sawit 


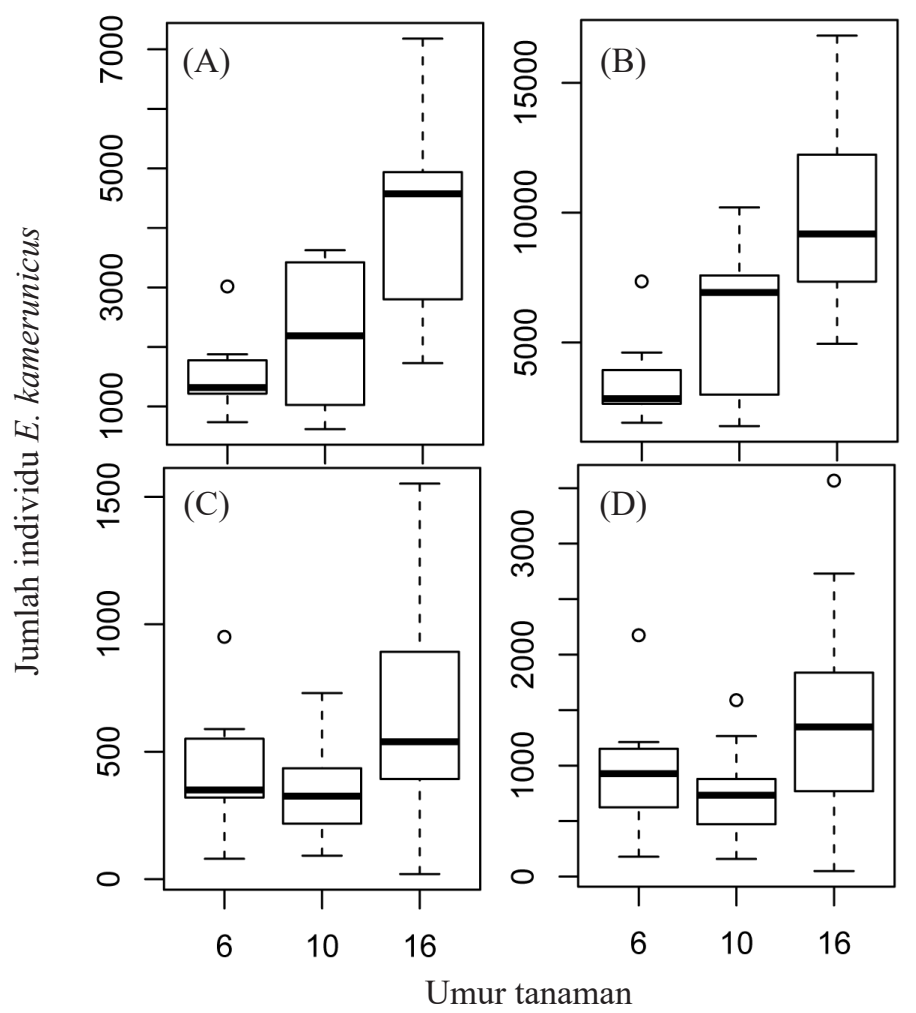

Gambar 4. Populasi Elaeidobius kamerunicus A: jantan; dan B: betina pada bunga jantan dan populasi E. kamerunicus C: jantan; dan D: betina pada bunga betina kelapa sawit pada umur tanaman berbeda.

berhubungan dengan penurunan jumlah bunga betina yang mekar $(\mathrm{r}=-0,778 ; \mathrm{P}<0,0001)$, tetapi tidak untuk bunga jantan $(\mathrm{r}=-0,034 ; \mathrm{P}=0,867)$ pada plot pengamatan.

\section{PEMBAHASAN}

Populasi E. kamerunicus pada bunga jantan dipengaruhi oleh umur tanaman kelapa sawit. Tanaman kelapa sawit umur 16 tahun memiliki ukuran tandan bunga jantan yang lebih besar (jumlah spikelet lebih banyak) dibandingkan dengan tandan bunga jantan pada kelapa sawit umur 6 dan 10 tahun. Pada spikelet bunga jantan terdapat serbuk sari yang merupakan sumber pakan kumbang E. kamerunicus sehingga apabila sumber pakan yang tersedia banyak maka populasi E. kamerunicus juga semakin meningkat. Hal ini sesuai dengan hasil penelitian Tandon et al. (2001) bahwa perbedaan populasi E. kamerunicus dan jumlah spikelet disebabkan oleh umur tanaman kelapa sawit. Semakin tua umur kelapa sawit maka jumlah spikelet akan semakin meningkat, yaitu dari sekitar 60 spikelet pada umur 3 tahun menjadi sekitar 150 spikelet pada umur 10 tahun. Hasil penelitian Kurniawan (2010) menunjukkan bahwa jumlah spikelet per tandan bunga jantan kelapa sawit berhubungan dengan populasi $E$. kamerunicus per tandan. Demikian juga, pada hasil penelitian Harumi (2011) menyatakan bahwa jumlah spikelet per tandan bunga jantan memiliki pengaruh yang cukup besar terhadap populasi kumbang.

Waktu atau bulan pengamatan yang hanya berbeda satu bulan diduga menyebabkan populasi E. kamerunicus yang diperoleh pada setiap pengamatan tidak berbeda. Berdasarkan hasil pelitian Wibowo (2010), tingginya populasi kumbang di bulan tertentu diduga berkaitan dengan tingginya serbuk sari yang ditunjukkan dari banyaknya jumlah spikelet per tandan pada bulan tersebut. Secara visual kemekaran bunga betina yang digunakan untuk pengamatan merupakan bunga betina mekar hari pertama, yaitu berwarna putih dan mekar hari kedua berwarna kuning gading. Oleh karena itu, senyawa volatil yang dikeluarkan bunga betina mekar cenderung sama sehingga tidak ada perbedaan populasi $E$. kamerunicus yang mengunjungi bunga betina. 
Menurut Rahayu (2009), tingkat kemekaran bunga betina menjadi salah satu faktor yang menentukan kualitas senyawa volatil yang dihasilkan bunga betina kelapa sawit.

Ditemukannya bias betina $E$. kamerunicus pada bunga jantan dan bunga betina pada keseluruhan umur kelapa sawit diduga berhubungan dengan sejarah hidup dari E. kamerunicus. Lama hidup imago E. kamerunicus betina lebih lama (65 hari) dibandingkan dengan imago E. kamerunicus jantan (46 hari). Lama waktu kumbang betina berkembang biak dan bereproduksi juga lebih panjang sehingga populasi kumbang betina lebih banyak dibandingkan dengan populasi kumbang jantan. Sesuai dengan penelitian Sholehana (2010) bahwa lama hidup imago betina lebih panjang dibandingkan dengan imago jantan. Hal ini tampaknya menyebabkan sedikitnya jumlah E. kamerunicus jantan yang terdapat pada bunga jantan kelapa sawit. Selain itu, sesuai dengan Kahono et al. (2012) bahwa E. kamerunicus betina adalah serangga yang paling aktif mengunjungi bunga betina dibandingkan dengan jantan, oleh sebab itu populasi E. kamerunicus betina akan lebih tinggi pada bunga betina kelapa sawit.

Persentase kunjungan E. kamerunicus pada tanaman berumur tua yang semakin rendah diduga menjadi salah satu faktor penurunan produktivitas kelapa sawit dengan semakin tuanya umur tanaman. Hal tersebut karena nilai kunjungan berhubungan dengan pembentukan fruit set. Meskipun populasi per hektar melebihi dari kehadiran minimal E. kamerunicus (20.000 individu/ha) (Balit Palma 2015), pembentukan fruit set tidak dapat mencapai optimal (Tandon et al. 2001). Oleh karena itu, optimalnya produktivitas kelapa sawit pada umur tanaman 8-12 tahun dan kemudian menurun secara perlahan sejalan dengan semakin bertambahnya umur kelapa sawit (Corley \& Tinker 2003) diduga dipengaruhi oleh penurunan kunjungan $E$. kamerunicus pada bunga betina.

\section{KESIMPULAN}

Berdasarkan hasil penelitian dapat disimpulkan bahwa umur tanaman kelapa sawit berpengaruh terhadap populasi E. kamerunicus pada bunga jantan, tetapi tidak pada bunga betina. Semakin tua umur kelapa sawit, populasi E. kamerunicus pada bunga jantan semakin meningkat. Rasio jenis kelamin E. kamerunicus yang ditemukan pada bunga jantan dan betina kelapa sawit cenderung bias betina. Berdasarkan perbandingan populasi E. kamerunicus pada bunga jantan dan betina pada setiap plot diperoleh bahwa nilai kunjungan $E$. kamerunicus paling tinggi ditemukan pada umur kelapa sawit muda.

\section{UCAPAN TERIMA KASIH}

Penelitian ini dibiayai oleh Badan Pengelola Dana Perkebunan (BPDP) Kelapa Sawit, Kementrian Keuangan. Ucapan terima kasih kami sampaikan kepada PT. Astra Agro Lestari yang memberikan fasilitas selama pelaksanaan penelitian di lapangan. Ucapan terima kasih juga disampaikan kepada Van Basten Tambunan, Saerozi, dan Amiruddin yang telah membantu pelaksanaan penelitian ini.

\section{DAFTAR PUSTAKA}

[Balit Palma] Balai Penelitian Tanaman Palma. 2015. Peran Elaeidobius kamerunicus sebagai Polinator di Pertanaman Kelapa Sawit. Tersedia di: http://balitka.litbang.pertanian.go.id/peranelaeidobius-kamerunicus-sebagai-polinatordipertanaman-kelapa-sawit. [accessed 27 Maret 2017].

Agus S, Roletha YP, Agus EP. 2007. Elaedobius kamerunicus, Serangga Penyerbuk Kelapa Sawit. Medan: Pusat Penelitian Kelapa Sawit.

Corley RHV, Tinker PB. 2003. The Oil Palm. Oxford: Blackwell Scientific. doi: https://doi. org/10.1002/9780470750971.

Harumi ER. 2011. Populasi Kumbang Elaeidobius kamerunicus Faust pada Tanaman Kelapa Sawit (Elaeis guineensis Jacq.) di PTPN VIII Cimulang, Bogor. Skripsi. Bogor: Institut Pertanian Bogor.

Kahono S, Lupiyaningdyah, Erniwati, Nugroho. 2012. Potensi dan pemanfaatan serangga penyerbuk untuk meningkatkan produksi kelapa sawit di perkebunan kelapa sawit Desa Api-api. Kecamatan Waru, Kabupaten Penajam Paser Utara, Kalimantan Timur. Jurnal Zoo Indonesia 21:23-34. 
Kurniawan Y. 2010. Demografi dan Populasi Kumbang Elaeidobius kamerunicus Faust. (Coleoptera: Curculionidae) sebagai Penyerbuk Kelapa Sawit (Elaeis guineensis Jacq.). Skripsi. Bogor: Institut Pertanian Bogor.

Lubis FI, Sudarjat, Dono D. 2017. Populasi serangga penyerbuk kelapa sawit Elaeidobius kamerunicus Faust. dan pengaruhnya terhadap nilai fruit set pada tanah berliat, berpasir dan gambut di Kalimantan Tengah, Indonesia. Jurnal Agrikultura 28:39-46.

Prasetyo AE, Susanto A. 2012. Serangga penyerbuk kelapa sawit Elaeidobius kamerunicus Faust.: agresivitas dan dinamika populasi di Kalimantan Tengah. Penelitian Kelapa Sawit 20:103-113.

Rahayu. 2009. Peran Senyawa Volatil Kelapa Sawit (Elaeis guineensis) dalam Penyerbukan oleh Serangga Elaeidobius kamerunicus (Coleoptera: Curculionidae) dan Thrips hawaiiensis di Bogor. Skripsi. Malang: Universitas Brawijaya.

Rahmadani, Achmad. 2015. Studi populasi serangga penyerbuk Elaeidobius kamerunicus pada tanaman kelapa sawit (Elaeis guieneensis Jacq.) di Kebun Bangun PTPN III, Kabupaten Simalungun. Jurnal Agrin 19:22-28.

Sholehana A. 2010. Demografi Kumbang Penyerbuk Kelapa Sawit Elaeidobius kamerunicus (Coleoptera: Curculionidae). Skripsi. Bogor: Institut Pertanian Bogor.
Simatupang B. 2014. Pemanfaatan Serangga Penyerbuk Kelapa Sawit (Elaeidobius kamerunicus) dalam Upaya Peningkatan Produktivitas Kelapa Sawit. Jambi: BPP Jambi.

Situmeang A, Tobing MC, Siregar AZ, Prasetyo AE. 2017. Penggunaan berbagai plasma nutfah kelapa sawit koleksi PPKS Riau terhadap populasi serangga penyerbuk kelapa sawit (Elaeidobius kamerunicus Faust.). Jurnal Pertanian Tropik 4:114-121.

Sunarko. 2007. Petunjuk Praktis Budi daya dan Pengolahan Kelapa Sawit. Jakarta: Agro Media Pustaka.

Tandon R, Manohara, Nijalingappa, Shivanna. 2001. Pollination and pollen-pistil interaction in oil palm. Annals of Botany 87:831-838. doi: https:// doi.org/10.1006/anbo.2001.1421.

Walker K. 2011. African Oil Palm Weevil (Elaeidobius kamerunicus). Available at: http:// www.padil.gov.au [accessed 20 Desember 2017].

Wibowo ES. 2010. Dinamika Populasi Kumbang Elaeidobius kamerunicus (Curculionidae: Coleoptera) sebagai Penyerbuk Kelapa Sawit (Elaeis guineensis Jacq.) Umur Enam Tahun. Skripsi. Bogor: Institut Pertanian Bogor. 